\title{
Iron deficiency among low income Canadian toddlers: a cross-sectional feasibility study in a Community Health Centre and non-Community Health Centre sites
}

Imaan Bayoumi ${ }^{1^{*}}$ (D), Patricia C. Parkin ${ }^{2,3,4,5}$, Gerald Lebovic ${ }^{4,6,7}$, Rupa Patel ${ }^{1,8}$, Kendra Link $^{8}$, Catherine S. Birken ${ }^{2,3,4,5}$, Jonathon L. Maguire $5,7,9,10$ and Cornelia M. Borkhoff $2,3,4$

\begin{abstract}
Background: Iron deficiency in early childhood has been associated with poor developmental outcomes. Little is known about the nutritional health of young children receiving care at Canadian Community Health Centres (CHCs). Our objectives were to describe iron deficiency among toddlers at an Ontario $\mathrm{CHC}$, to compare young children attending $\mathrm{CHCs}$ and non-CHCs, and assess the feasibility of conducting research on children in $\mathrm{CHC}$ settings.

Methods: One CHC, Kingston Community Health Centres (CHC) with two clinical sites and one community programming site was added to the nine non-CHC pediatric and primary care clinics in the existing TARGet Kids! research network. A cross-sectional feasibilitystudy was conducted.and. Healthy children, ages 12-36 months were Enrolled. iron deficiency without inflammation (ferritin $<14 \mu \mathrm{g} / \mathrm{L}$ and $C R P<10 \mathrm{mg} / \mathrm{L}$ ) and serum ferritin were assessed. Adjusted multivariable regression analyses were used to evaluate an association between CHC enrolment and iron status.

Results: The CHC cohort ( $n=31$ ) was older, had lower household income, lower maternal education, higher nutrition risk scores, higher cow's milk intake, shorter breastfeeding duration and higher prevalence of unhealthy weights compared with the non-CHC cohort $(n=875)$. There was no association between $\mathrm{CHC}$ status and serum ferritin (difference in median serum ferritin $4.78 \mu \mathrm{g} / \mathrm{L}, 95 \%$ confidence interval $[\mathrm{Cl}]-2.5,14.3, p=0.22)$ or iron deficiency (OR 0.55 , $95 \% \mathrm{Cl} 0.11,-2.73, p=0.46)$ using multivariable linear and logistic regression, respectively.
\end{abstract}

Conclusion: Despite differences in sociodemographic variables, we did not detect a difference in iron status between toddlers enrolled at CHCs compared to non-CHC settings. Further research is needed to understand the health effects of poverty generally, and iron deficiency specifically among children receiving care at CHCs.

Keywords: Early childhood, Iron deficiency, Social determinants of health

\footnotetext{
* Correspondence: imaan.bayoumi@dfm.queensu.ca

'Department of Family Medicine, Queen's University, 220 Bagot St., P.O. Bag

8888, Kingston, ON K7L5E9, Canada

Full list of author information is available at the end of the article
}

(c) The Author(s). 2018 Open Access This article is distributed under the terms of the Creative Commons Attribution 4.0 International License (http://creativecommons.org/licenses/by/4.0/), which permits unrestricted use, distribution, and reproduction in any medium, provided you give appropriate credit to the original author(s) and the source, provide a link to the Creative Commons license, and indicate if changes were made. The Creative Commons Public Domain Dedication waiver (http://creativecommons.org/publicdomain/zero/1.0/) applies to the data made available in this article, unless otherwise stated. 


\section{Background}

Healthy term infants are born with adequate stored iron. However, without ongoing adequate intake, non-anemic iron deficiency (NAID) can develop and progress to iron deficiency anemia (IDA), which has been associated with long lasting and potentially irreversible impaired mental and psycho-motor development [1-4].

Infants and toddlers are vulnerable to iron deficiency because their natural diet tends to be low in iron and their needs are high due to rapid growth. There are no nationally representative data but regional studies suggest a prevalence among young Canadian children of $12 \%$ or higher for NAID and $1.5 \%$ or higher for IDA, [5] which is comparable to U.S. findings $[6,7]$.

TARGet Kids! (www.targetkids.ca), an innovative practice-based research network has recruited more than 10,000 young children, mostly located in Greater Toronto area, Canada during their regularly scheduled health maintenance visits with their primary care providers since 2008. Iron deficiency prevalence and risk factors have been studied in this cohort [8-15].

In the province of Ontario, Canada, 74 publically funded Community Health Centres (CHCs) provide primary health care to over 30,000 young children under age 6 years. Children accessing health care from $\mathrm{CHCs}$ may be at increased risk for poor health outcomes due to a high prevalence of poverty and low parental educational attainment [16-18]. CHCs have been identified as an ideal setting for studying child health, however to date there has been no previous research conducted on young children attending CHCs [19].

The Rourke Baby Record, a Canadian evidence-based guide endorsed by the Canadian Paediatric Society and the College of Family Physicians of Canada for health supervision for well child care recommends screening high risk infants for anemia, but makes no recommendation on screening for iron deficiency in young children [20].

If children attending $\mathrm{CHCs}$ are at increased risk for iron deficiency, they could be targeted for screening. Therefore, our primary objective was to describe iron deficiency among toddlers attending CHCs through the addition of a CHC site to the TARGet Kids! network; and our secondary objective was to determine whether $\mathrm{CHC}$ attendance, was associated with iron deficiency in early childhood.

\section{Methods}

We performed a multi-centre cross-sectional feasibility study. We recruited the $\mathrm{CHC}$ sample from December 2013 to August 2014 from Kingston Community Health Centres (KCHC) including two clinical sites (North Kingston Community Health Centre and Napanee Area Community Health Centre) and a community site
(Better Beginnings for Kingston Children) which offers programs for families with children age $0-5$ years living in north Kingston, including prenatal education, home visiting and parenting programs. Parents of potentially eligible children were invited to participate by letter, with a follow up phone or text message. We attempted to remove barriers to participation by providing transportation, childcare, snacks and a $\$ 10$ grocery card.

The non-CHC sample comprised children participating in TARGet Kids! recruited by study personnel embedded at 9 participating pediatric and primary care practices in Toronto, Canada between June 2008 and March 2015. The TARGet Kids! cohort profile has been previously described [8]. Data for the non-CHC sample were abstracted from the TARGet Kids! database.

We enrolled healthy children ages 12 to 36 months, with their guardian's written consent. Children were ineligible to participate if they had a previously diagnosed developmental disorder, genetic, chromosomal or syndromic condition, chronic medical condition (other than asthma and allergies), were born prematurely (gestational age less than 35 weeks), birth weight less than $2500 \mathrm{~g}$, had an acute illness such as a viral illness or whose parent was unable to communicate in English. For the purpose of this study, children were included if they had complete data on outcome variables including serum ferritin, and C-reactive protein (CRP). Children with $\mathrm{CRP} \geq 10 \mathrm{mg} / \mathrm{L}$ were excluded since this elevation may indicate acute systemic inflammation [21, 22]. If a child's record contained data from multiple visits, the first visit with complete data was used for analysis.

Research ethics approval was granted by Queen's University Health Sciences Research Ethics Board (CHC sample), and the Research Ethics Boards of the Hospital for Sick Children and St. Michael's Hospital (non-CHC, TARGet Kids!).

\section{Measures}

Parents completed the study instruments, including one based on the Canadian Community Health Survey, [23] addressing child and family characteristics, child diet and health behaviours and the NutriSTEP ${ }^{\odot}$ questionnaire, a 17-item validated nutritional risk assessment tool $[24,25]$. Child weight and height were assessed - according to standardized anthropometric protocols [26]. Venous blood was drawn by trained research personnel, at least $30 \mathrm{~min}$ after the application of Ametop ${ }^{\circ}$ to reduce phlebotomy-associated pain. Samples from the $\mathrm{CHC}$ group were tested at Kingston General Hospital (www.kgh.on.ca/) for the complete blood count (CBC) and at Mount Sinai Services (www.mountsinaiservices. $\mathrm{com} /$ ) for serum ferritin and C-reactive protein (CRP) analysis. For the non-CHC group, samples were tested at Mount Sinai Services. 


\section{Outcome variables}

Our main outcome was iron status, measured by serum ferritin $(\mu \mathrm{g} / \mathrm{L})$ in the absence of inflammation, as recommended by the US National Health and Nutrition Examination Survey [27]. A secondary outcome was hemoglobin. Ferritin was used as a continuous and categorical variable (iron deficiency defined as ferritin $<14 \mu \mathrm{g} / \mathrm{L}$ which was the cut-off used in the US National Health and Nutrition Examination Survey).

\section{Covariates}

We adjusted our analysis for several pre-specified variables previously reported to influence iron status, including age, sex, body mass index z-score (zBMI), [28] total breastfeeding duration [13] (number of months determined by parental response to the question "For how long has your child been breastfed? - classified as 0 months for children who were never breastfed and their current age for those currently breastfeeding), cow's milk intake [12] (classified as 2 cups or more- yes/ no, consistent with nutritional recommendations) and meat and meat-alternatives consumption [14] (determined by the NutriSTEP ${ }^{\circledR}$ question "My child usually eats meat, fish, poultry, or alternatives (alternatives can be eggs, peanut butter, tofu, nuts, and cooked beans, chickpeas and lentils): 1) More than 2 times a day; 2) Two times a day; 3) Once a day; 4) A few times a week; 5) Not at all."). We also included iron supplementation (including a multivitamin containing iron) as a covariate. Income and education were also included as potential confounding variables, anticipating a difference in these socioeconomic variables between the $\mathrm{CHC}$ and non$\mathrm{CHC}$ groups, and with low socioeconomic status previously reported as a risk factor for iron deficiency in early childhood [29].

\section{Statistical analysis}

We performed descriptive statistics for the main outcomes and covariates. Two multivariable models were constructed. We used a linear regression model to assess the association between $\mathrm{CHC}$ attendance and serum ferritin level (as a continuous measure). Serum ferritin was log transformed as residual analysis using the untransformed outcome indicated a violation of the normality assumption. The outcome was then back-transformed to aid in interpretation of results. We used a logistic regression model to evaluate the association between $\mathrm{CHC}$ attendance and iron deficiency (using serum ferritin level as a binary measure: serum ferritin value $<14 \mu \mathrm{g} / \mathrm{L}$ or $\geq 14 \mu \mathrm{g} / \mathrm{L})$. Both models were adjusted for all the covariates previously described regardless of statistical significance [30]. All covariates had less than 10\% missing data, with the exception of maternal education, which had $24 \%$ missing data, and family income, which had
33\% missing data. We included maternal education and family income as covariates to reduce bias in the estimate after confirming that both were confounders using the $10 \%$ change-in-estimate criterion [31]. Missing data fit the missing-at-random criterion; we used multiple imputation with 50 imputed datasets methods using the fully conditional specification method to analyze these data [32]. Statistical significance was defined as $p<0.05$. All statistical tests were two-sided. All analyses were conducted using SAS 9.4 (SAS Institute, Cary, NC).

\section{Results}

Of 310 eligible children at KCHC, 143 declined or could not be reached prior to their third birthday, 111 could not be reached (phone numbers not in service, had no phone or did not respond to a phone or text message) and 15 did not attend a scheduled visit. Forty-one parents consented to their children's participation and phlebotomy was successful in 31, and none had C-reactive protein values $>10 \mathrm{mg} / \mathrm{L}$. A total of 2619 eligible children from the non-CHC sites consented to participate; of these, 1309 had blood assessed for serum ferritin. Of the 1309 children with serum ferritin values, 902 had data on meat consumption (this sample represented an early datacut for the paper by Cox et al. [14]. Of these, 27 children had C-reactive Protein levels $\geq 10 \mathrm{mg} / \mathrm{L}$ and were excluded. Therefore, there were 875 children from the non- $\mathrm{CHC}$ sites who met the inclusion criteria. Previous TARGet Kids! work has found those who opt to have blood sampled are similar in demographics to those who do not [13].

The CHC $(n=31)$ and non-CHC $(n=875)$ samples with blood results differed in their sociodemographic characteristics and health behaviours (Table 1). The CHC sample was older, had lower household income, lower maternal education and differed in maternal ethnicity. The $\mathrm{CHC}$ sample had higher nutritional risk as assessed by the NutriSTEP ${ }^{\oplus}$, greater frequency of intake of cow's milk exceeding two cups daily and shorter median duration of breastfeeding. Furthermore, growth parameters differed between the two groups; the $\mathrm{CHC}$ group had a higher prevalence of both underweight and overweight or obese children compared with the non-CHC cohort. Hematological results in the $\mathrm{CHC}$ cohort compared with the non-CHC cohort were hemoglobin (median, range) $121 \mathrm{~g} / \mathrm{L}$ (99-140) vs. $121 \mathrm{~g} /$ $\mathrm{L}(78-147)$, ferritin $28 \mu \mathrm{g} / \mathrm{L}(4-202)$ vs. $25 \mu \mathrm{g} / \mathrm{L}(2-159)$, iron deficiency (ferritin $<14 \mu \mathrm{g} / \mathrm{L}$ ) $9.7 \%$ vs. $18.1 \%$, iron deficiency anemia $(\mathrm{Hb}<110 \mathrm{~g} / \mathrm{L}$, ferritin $<14 \mu \mathrm{g} / \mathrm{L}) 3.2 \%$ vs. $2.4 \%$.

We found no association in the univariate analysis or in the adjusted model between $\mathrm{CHC}$ status (yes/no) and iron deficiency (ferritin $<14 \mu \mathrm{g} / \mathrm{L}$ ) using multivariable logistic regression (OR 0.55, 95\% confidence interval 
Table 1 Baseline characteristics of study cohort by exposure variable: CHC attendance

\begin{tabular}{|c|c|c|c|}
\hline Variable & Total & Attends $\mathrm{CHC}^{\mathrm{a}}$ & Does not attend $\mathrm{CHC}^{\mathrm{a}}$ \\
\hline Total sample & 906 & $31(3.4)$ & $875(96.6)$ \\
\hline Age (months) & $19.5(12.2,36.5)$ & $26.2(12.9,36.4)$ & $19.2(12.2,36.5)$ \\
\hline Sex, male & $481(53.1)$ & $14(45.2)$ & $467(53.4)$ \\
\hline \multicolumn{4}{|l|}{ Maternal Ethnicity } \\
\hline European & $623(68.8)$ & $22(71.0)$ & $601(68.7)$ \\
\hline Asian & $165(18.2)$ & $1(3.2)$ & $164(18.7)$ \\
\hline African/Caribbean/ Latin American & $68(7.5)$ & $3(9.7)$ & $65(7.4)$ \\
\hline Indigenous & $4(0.4)$ & $2(6.5)$ & $2(0.2)$ \\
\hline Missing & $46(5.1)$ & $3(9.7)$ & $43(4.9)$ \\
\hline \multicolumn{4}{|l|}{ Child immigration status } \\
\hline Canadian & $858(94.7)$ & $31(100)$ & $827(94.5)$ \\
\hline Landed immigrant & $20(2.2)$ & 0 & $20(2.3)$ \\
\hline Missing & $28(3.1)$ & 0 & $28(3.2)$ \\
\hline \multicolumn{4}{|l|}{ Self-report family income } \\
\hline$\$ 0-29,999$ & $54(6.0)$ & $19(61.3)$ & $35(4.0)$ \\
\hline$\$ 30,000-79,999$ & $85(9.4)$ & $6(19.4)$ & $79(9.0)$ \\
\hline$\geq \$ 80,000$ & $469(51.8)$ & $2(6.5)$ & $467(53.4)$ \\
\hline Missing & $298(32.9)$ & $4(12.9)$ & $294(33.6)$ \\
\hline \multicolumn{4}{|l|}{ Maternal education } \\
\hline High school or less & $83(9.2)$ & $20(64.5)$ & $63(7.2)$ \\
\hline Post-secondary & $603(66.6)$ & $10(32.3)$ & $593(67.8)$ \\
\hline Missing & $220(24.3)$ & $1(3.2)$ & $219(25.0)$ \\
\hline Daily iron supplementation, yes & $35(3.9)$ & $3(9.7)$ & $32(3.7)$ \\
\hline Missing & $3(0.3)$ & 0 & $3(0.3)$ \\
\hline Daily cow's milk intake (cups) & $2.0(0,5)$ & $3.0(0,5)$ & $2.0(0,5)$ \\
\hline Daily cow's milk intake $>2$ cups & $278(30.7)$ & $17(54.8)$ & $261(29.8)$ \\
\hline Missing & $93(10.3)$ & $2(6.5)$ & $91(10.4)$ \\
\hline NutriSTEP® total score & $12(1,39)$ & $17(6,34)$ & $12(1,39)$ \\
\hline Missing & $208(23.0)$ & $1(3.2)$ & $207(23.7)$ \\
\hline \multicolumn{4}{|l|}{ BMI } \\
\hline Underweight $(z<-2)$ & $23(2.5)$ & $2(6.5)$ & $21(2.4)$ \\
\hline Healthy weight $(-2 \geq z \leq 1)$ & $682(75.3)$ & $21(67.7)$ & $661(75.5)$ \\
\hline At risk overweight $(1>z \leq 2)$ & $124(13.7)$ & $5(16.1)$ & $119(13.6)$ \\
\hline Overweight $(2<z \leq 3)$ & $42(4.6)$ & $3(9.7)$ & $39(4.5)$ \\
\hline Obese $(z>3)$ & $4(0.4)$ & 0 & $4(0.5)$ \\
\hline Missing & $31(3.4)$ & 0 & $31(3.5)$ \\
\hline Breastfeeding duration, mo & $\begin{array}{l}11.0(0,35.9) \\
17(1.9)\end{array}$ & $\begin{array}{l}2.0(0,23.8) \\
0\end{array}$ & $\begin{array}{l}11.0(0,35.9) \\
17(1.9)\end{array}$ \\
\hline \multicolumn{4}{|l|}{ Meat/meat alternatives consumption } \\
\hline More than twice daily & $209(23.1)$ & $5(16.1)$ & $204(23.3)$ \\
\hline Twice daily & $442(48.8)$ & $14(45.2)$ & $428(48.9)$ \\
\hline Once daily & $186(20.5)$ & $7(22.6)$ & $179(20.5)$ \\
\hline A few times weekly & $62(6.8)$ & $2(6.5)$ & $60(6.9)$ \\
\hline Not at all & $6(0.7)$ & $2(6.5)$ & $4(0.5)$ \\
\hline
\end{tabular}


Table 1 Baseline characteristics of study cohort by exposure variable: CHC attendance (Continued)

\begin{tabular}{llll}
\hline Variable & Total & Attends $\mathrm{CHC}^{\mathrm{a}}$ & Does not attend $\mathrm{CHC}^{\mathrm{a}}$ \\
\hline \multicolumn{1}{c}{ Missing } & $1(0.1)$ & $1(3.2)$ & 0 \\
$\mathrm{CRP}(\mathrm{mg} / \mathrm{L})$ & $0.3(0.1,9.7)$ & $0.5(0.1,4.8)$ & $0.3(0.1,9.7)$ \\
Serum ferritin $(\mu \mathrm{g} / \mathrm{L})$ & $25(2,202)$ & $28(4,202)$ & $25(2,159)$ \\
Iron deficiency, yes & $161(17.8)$ & $3(9.7)$ & $158(18.1)$ \\
(serum ferritin $<14 \mu \mathrm{g} / \mathrm{L})$ & $121.0(78,147)$ & $120.5(99,140)$ & $121.0(78,147)$ \\
Hemoglobin $(\mathrm{g} / \mathrm{L})$ & $43(4.8 \%)$ & $3(9.7 \%)$ & $40(4.6 \%)$ \\
$\quad$ & & & $20(2.3)$ \\
Missing & $21(2.3)$ & $1(3.2)$ & $40(4.6)$
\end{tabular}

zBMI indicates body mass index z score

${ }^{\mathrm{a}}$ Data are presented as $\mathrm{n}(\%)$ or median (range)

$0.11-2.73, p=0.46$ ) (Table 2). Statistically significant covariates associated with an increased odds of iron deficiency included younger age, higher zBMI, longer total breastfeeding duration, lower meat and meat-alternatives consumption, and lower CRP.

In the univariate linear regression, $\mathrm{CHC}$ status was associated with higher serum ferritin (change in serum ferritin $6.73 \mu \mathrm{g} / \mathrm{L}[0.32,14.76, p=0.04]$ ), however, no association was found in the adjusted multivariable linear regression model (change in serum ferritin of $4.8 \mu \mathrm{g} / \mathrm{L}$ $(-2.5,14.3, p=0.22)$ for children enrolled from the $\mathrm{CHC}$ ) (Table 3 ). Statistically significant covariates associated with lower serum ferritin included higher zBMI, longer total breastfeeding duration, cow's milk intake greater than two cups daily, lower CRP, and low family income.

\section{Discussion}

In this study of healthy 12-36 month old Canadian children, $9.7 \%$ of those attending $\mathrm{CHCs}$ had non-anemic iron deficiency versus $18.1 \%$ of children receiving care in non-CHC sites. We found that despite lower socioeconomic status, there was no association between $\mathrm{CHC}$ attendance and iron status. Instead, feeding practices were significant predictors of iron status. The lower prevalence of iron deficiency among children attending $\mathrm{CHCs}$ may be explained by the relative distribution of risk and protective factors. For example, the $\mathrm{CHC}$ sample had a higher proportion of children with daily cow's milk intake $>2$ cups/day, lower meat and meat-alternatives consumption, and unhealthy weights, but shorter breastfeeding duration. In addition, the small sample size of the $\mathrm{CHC}$ cohort may have been an explanatory factor.

Table 2 Multivariable logistic regression model for association between CHC status and iron deficiency (serum ferritin < $14 \mu \mathrm{g} / \mathrm{L}$ )

\begin{tabular}{|c|c|c|c|}
\hline Predictor & $\beta(95 \% \mathrm{Cl})$ & $\mathrm{OR}(\mathrm{Cl})$ & $P$ \\
\hline $\mathrm{CHC}$, yes & $-0.60(-2.21,1.01)$ & $0.55(0.11,2.73)$ & 0.46 \\
\hline Age, mo & $-0.03(-0.06,-0.001)$ & $0.97(0.94,1.00)$ & $0.04^{*}$ \\
\hline Female sex & $-0.20(-0.55,0.16)$ & $0.82(0.57,1.17)$ & 0.28 \\
\hline \multicolumn{4}{|l|}{ Income } \\
\hline$\$ 0-29,999$ & $0.63(-0.14,1.39)$ & $1.88(0.87,4.03)$ & 0.84 \\
\hline$\$ 30,000-79,999$ & $-0.06(-0.69,0.56)$ & $0.94(0.50,1.75)$ & 0.17 \\
\hline \multicolumn{4}{|l|}{$\geq \$ 80,000$ (Reference) } \\
\hline Maternal education (Post-secondary, no) & $-0.57(-1.37,0.24)$ & $0.57(0.25,1.27)$ & 0.17 \\
\hline zBMI, unit & $0.25(0.09,0.42)$ & $1.29(1.09,1.52)$ & $0.004^{*}$ \\
\hline Breastfeeding duration, mo & $0.04(0.01,0.07)$ & $1.04(1.01,1.08)$ & $0.005^{*}$ \\
\hline Milk consumption ( $>2$ cups daily), yes & $0.34(-0.04,0.73)$ & $1.41(0.96,2.08)$ & 0.08 \\
\hline Meat/ meat alternatives consumption & $0.21(-0.41,-0.005)$ & $0.81(0.66,0.99)$ & 0.04 \\
\hline $\mathrm{CRP}(\mathrm{mg} / \mathrm{L})$ & $-0.23(-0.42,0.04)$ & $0.79(0.66,0.96)$ & $0.02^{*}$ \\
\hline Iron/ multivitamin Supplementation, yes & $0.01(-0.92,0.95)$ & $1.01(0.40,2.59)$ & 0.98 \\
\hline
\end{tabular}

OR indicates odds ratio; zBMI indicates body mass index z score; Cl indicates confidence interval; CRP indicates C-reactive protein. Adjusted $\beta$ estimates are reported to 2 decimal points for statistical precision. Negative values indicate a decrease in iron deficiency, positive values indicate an increase in iron deficiency. *indicates statistically significant effects 
Table 3 Multivariable linear regression model for association between CHC status and serum ferritin

\begin{tabular}{|c|c|c|c|c|c|c|}
\hline \multirow[t]{2}{*}{ Predictor } & \multirow[t]{2}{*}{$\beta(\log )$} & \multirow[t]{2}{*}{$95 \% \mathrm{Cl}$} & \multirow{2}{*}{$\begin{array}{l}\text { Change in } \\
\text { serum ferritin, \% }\end{array}$} & \multicolumn{2}{|c|}{ Change in median serum ferritin } & \multirow[t]{2}{*}{$P$} \\
\hline & & & & $\mu \mathrm{g} / \mathrm{l}$ & $95 \% \mathrm{Cl}$ & \\
\hline $\mathrm{CHC}$, yes & 0.17 & $-0.10,-0.45$ & 19.12 & 4.78 & $-2.46,14.34$ & 0.22 \\
\hline Age, mo & -0.0006 & $-0.01,0.01$ & 0.06 & 0.14 & $-0.15,0.18$ & 0.87 \\
\hline Female sex & 0.08 & $0.003,0.16$ & 8.01 & 2.00 & $0.07,4.25$ & 0.06 \\
\hline \multicolumn{7}{|l|}{ Income } \\
\hline$\$ 0-29,999$ & -0.23 & $-0.41,-0.04$ & -20.17 & -5.04 & $-8.48,-0.89$ & $0.02^{*}$ \\
\hline$\$ 30,000-79,999$ & 0.02 & $-0.11,0.15$ & 1.97 & 0.49 & $-2.69,4.12$ & 0.77 \\
\hline \multicolumn{7}{|l|}{$\geq \$ 80,000$ (Reference) } \\
\hline Maternal education (Post-secondary, no) & 0.08 & $-0.09,0.24$ & 7.93 & 1.98 & $02.10,6.79$ & 0.36 \\
\hline zBMI, unit & -0.07 & $-0.10,-0.03$ & -6.49 & -1.62 & $-2.49,0.71$ & $0.0006^{*}$ \\
\hline Breastfeeding duration, mo & -0.01 & $-0.02,-0.01$ & -1.46 & -0.37 & $-0.54,-0.20$ & $<.0001^{*}$ \\
\hline Milk consumption ( $>2$ cups daily) & -0.11 & $-0.20,-0.02$ & -10.37 & -2.59 & $-4.49,-0.52$ & $0.02^{*}$ \\
\hline Meat / fish consumption daily & 0.01 & $-0.04,0.06$ & 0.94 & 0.24 & $-0.91,1.44$ & 0.69 \\
\hline $\mathrm{CRP}(\mathrm{mg} / \mathrm{L})$ & 0.07 & $0.05,0.10$ & 7.69 & 1.92 & $1.17,2.70$ & $<0.0001^{*}$ \\
\hline Iron/ multivitamin supplementation & 0.04 & $-0.16,0.25$ & 4.50 & 1.13 & $-3.80,7.20$ & 0.68 \\
\hline
\end{tabular}

zBMI indicates body mass index z score; $\mathrm{Cl}$ indicates confidence interval; $\mathrm{CRP}$ indicates $\mathrm{C}$-reactive protein

Adjusted $\beta$ estimates are reported to 2 decimal points for statistical precision. Negative values indicate a decrease in median serum ferritin, positive values indicate an increase in median serum ferritin. ${ }^{*}$ indicates statistically significant effects

The association between social determinants and iron deficiency has been examined by other investigators. Small Canadian regional studies have identified a high prevalence of NAID and IDA in children residing in remote Indigenous communities [33-37]. In the U.S., Europe and New Zealand, several studies have identified an association between social factors (low income, [38-41] race/ ethnicity [38, 39, 42, 43] and immigration status [40]) and iron deficiency. The Rourke Baby Record recommends screening for anemia in high risk infants (low SES, some ethnic groups, low birthweight and premature infants and those with excessive milk intake) [20]. The American Academy of Pediatrics recommends universal screening using hemoglobin and risk assessment, including children of low socioeconomic status and of Mexican American decent. Our findings suggest that risk stratification on the basis of feeding practices, rather than social determinants alone, may be a more appropriate strategy for early identification of iron deficiency, a hypothesis which should be empirically tested. Given the high overall prevalence of iron deficiency in this age group, this strategy may be warranted in both $\mathrm{CHC}$ and non-CHC settings.

Studies of children with iron deficiency have been largely conducted in developing countries due to the high prevalence. Poor developmental outcomes have been summarized in several reviews of observational studies [1, 44, 45]. A longitudinal study of Costa Rican infants enrolled at 12-23 months and followed to 25 years, showed that the developmental disadvantage persists long term despite iron therapy [46, 47]. These include cognitive impairments (cognitive scores 9 points lower compared with healthy controls) and functional impairments such as non-completion of secondary school and poor emotional health [46, 47]. In addition, case-series and case-control studies suggest an association between iron deficiency anemia and childhood stroke $[48,49]$.

Extensive evidence has established that biological, physical and social exposures during early childhood have been associated with long term adult health effects, [50-55] but little data exist on the health effects of child poverty in the Canadian context. CHCs may represent an untapped potential to better understand the health needs of vulnerable children.

Strengths of our study include that it is the first published report of the nutritional health of children at Canadian CHCs, as well as the large size of the non- $\mathrm{CHC}$ cohort. The $\mathrm{CHC}$ model is intended to target socially vulnerable patients [56]. This research provides a preliminary view of the social and nutritional vulnerability of this population and supports the importance of additional research to better understand their health needs, [19] in order to inform the development of interventions aimed at reducing health disparities.

The small size of the $\mathrm{CHC}$ cohort is an important study limitation, which limits our power to detect a meaningful difference that may exist. Recruitment in the $\mathrm{CHC}$ setting was challenging, despite steps taken to try to reduce barriers to participation including providing transportation, childcare, snacks and a small incentive. Many potential participants could not be reached because 
their contact information was out of date or they had no telephone, demonstrating the financially precarious situation for many families. Future recruitment may be more successful if undertaken during regularly scheduled clinic visits. Alternatively, $\mathrm{CHC}$ staff could be engaged in recruitment and data collection, using research funds for cost recovery, with careful attention to minimizing disruption of clinic workflow. A larger study is needed to address the research questions, to optimize potentially modifiable risk factors for poor developmental outcomes. In addition, our results may be subject to recall bias. It is not known whether recall errors would differ between the two groups.

\section{Conclusion}

Children receiving care at Ontario $\mathrm{CHCs}$ have higher social and nutritional risk but we did not identify differences in iron status compared with non-CHC children. Further research is needed to understand the health implications of social adversity in general, and iron deficiency in particular, in the $\mathrm{CHC}$ cohort.

\section{Abbreviations}

CBC: Complete blood count; CHC: Community Health Centre; CRP: C-reactive protein; IDA: Iron deficiency anemia; NAID: Non-anemic iron deficiency; z BMI: Body mass index z-score

\section{Acknowledgements}

We thank all of the participating families for their time and involvement in TARGet Kids! and are grateful to all practitioners who are currently involved in the TARGet Kids! practice-based research network. We are also grateful to the staff and volunteers at Kingston Community Health Centres who supported this project including Tammy Punchard, Candice Blizzard, Vicki Kimmett, Janice Webb, Suzanne Becker, Hersh Sehdev and the members of the Indigenous Health Council. COLLABORATORS *TARGet Kids! Collaborators-Co-Leads: Catherine S. Birken, Jonathon L. Maguire; Advisory Committee: Ronald Cohn, Eddy Lau, Andreas Laupacis, Patricia C. Parkin, Michael Salter, Peter Szatmari, Shannon Weir; Science Review and Management Committees: Laura N. Anderson, Cornelia M. Borkhoff, Charles Keown-Stoneman, Christine Kowal, Dalah Mason; Site Investigators: Murtala Abdurrahman, Barbara Anderson, Kelly Anderson, Gordon Arbess, Jillian Baker, Tony Barozzino, Sylvie Bergeron, Dimple Bhagat, Nicholas Blanchette, Gary Bloch, Joey Bonifacio, Ashna Bowry, Anne Brown, Jennifer Bugera, Caroline Calpin, Douglas Campbell, Sohail Cheema, Elaine Cheng, Brian Chisamore, Evelyn Constantin, Ellen Culbert, Karoon Danayan, Paul Das, Mary Beth Derocher, Anh Do, Michael Dorey, Kathleen Doukas, Anne Egger, Allison Farber, Amy Freedman, Sloane Freeman, Sharon Gazeley, Charlie Guiang, Dan Ha, Curtis Handford, Laura Hanson, Leah Harrington, Hailey Hatch, Teresa Hughes, Sheila Jacobson, Lukasz Jagiello, Gwen Jansz, Mona Jasuja, Paul Kadar, Tara Kiran, Holly Knowles, Bruce Kwok, Sheila Lakhoo, Margarita Lam-Antoniades, Eddy Lau, Denis Leduc, Fok-Han Leung, Alan Li, Patricia Li, Jennifer Loo, Joanne Louis, Sarah Mahmoud, Jessica Malach, Roy Male, Vashti Mascoll, Aleks Meret, Elise Mok, Rosemary Moodie, Julia Morinis, Maya Nader, Katherine Nash, Sharon Naymark, James Owen, Jane Parry, Michael Peer, Kifi Pena, Marty Perlmutar, Navindra Persaud, Andrew Pinto, Michelle Porepa, Vikky Qi, Nasreen Ramji, Noor Ramji, Jesleen Rana, Danyaal Raza, Alana Rosenthal, Katherine Rouleau, Janet Saunderson, Rahul Saxena, Vanna Schiralli, Michael Sgro, Hafiz Shuja, Susan Shepherd, Barbara Smiltnieks, Cinntha Srikanthan, Carolyn Taylor, Stephen Treherne, Suzanne Turner, Fatima Uddin, Meta van den Heuvel, Joanne Vaughan, Thea Weisdorf, Sheila Wijayasinghe, Peter Wong, Anne Wormsbecker, John Yaremko, Ethel Ying, Elizabeth Young, Michael Zajdman; Research Team: Farnaz Bazeghi, Vincent Bouchard, Marivic Bustos, Charmaine Camacho, Dharma Dalwadi, Christine Koroshegyi, Tarandeep Malhi, Sharon Thadani, Julia Thompson, Laurie Thompson; Project Team: Mary Aglipay, Imaan Bayoumi, Sarah Carsley, Katherine Cost, Karen Eny, Theresa Kim, Laura Kinlin, Jessica Omand, Shelley Vanderhout,
Leigh Vanderloo; Applied Health Research Centre: Christopher Allen, Bryan Boodhoo, Olivia Chan, David W.H. Dai, Judith Hall, Peter Juni, Gerald Lebovic, Karen Pope, Kevin Thorpe; Mount Sinai Services Laboratory: Rita Kandel, Michelle Rodrigues, Hilde Vandenberghe, Azar Azad. Kingston General Hospital Laboratory: Joyce deVette-McPhail, Sandip SenGupta, Dr. David Good.

\section{Funding}

Funding for this project was provided by a Janus Grant from the College of Family Physicians in Canada. Funding to support TARGet Kids! was provided by multiple sources including the Canadian Institutes for Health Research (CIHR), namely the Institute of Human Development, Child and Youth Health [No. MOP 114945 to JLM, No. MOP 115059 to PCP] and the Institute of Nutrition, Metabolism and Diabetes [No. MOP 119375 to CSB], as well as, the St. Michael's Hospital Foundation. The Paediatric Outcomes Research Team (PORT) is supported by a grant from The Hospital for Sick Children Foundation. Funding agencies had no role in the design, collection, analyses or interpretation of the results of this study or in the preparation, review, or approval of the manuscript.

\section{Availability of data and materials}

Data are available upon request by contacting www.targetkids.ca/contact-us/. The full data are not freely available to respect the confidentiality of our participants, ensure data integrity, and avoid scientific overlap between projects. Once initial contact has been made, we request a short research proposal which will be subject to review by the TARGet Kids! Scientific Committee and approval by institutional IRBs.

\section{Authors' contributions}

All authors (IB, PCP, GL, RP, KL, CSB, JLM, CMB) made substantial contributions to the conception and study design, data acquisition, and interpretation of study results. Data analysis was conducted by IB, CMB and GL. All authors read and approved the final manuscript.

\section{Ethics approval and consent to participate}

Research ethics approval was granted by Queen's University Health Sciences Research Ethics Board (CHC cohort), Hospital for Sick Children and St. Michael's Hospital (non-CHC, TARGet Kids!). We enrolled healthy children ages 12 to 36 months, with their guardian's written consent.

\section{Consent for publication}

Not applicable.

\section{Competing interests}

IB reports receiving a grant from the College of Family Physicians of Canada for the conduct of this study. Funding to support TARGet Kids! was provided by multiple sources, including the Canadian Institutes for Health Research $(\mathrm{ClHR})$, namely the Institute of Human Development, Child and Youth Health (No. MOP 114945 to JLM, No. MOP 115059 to PCP, No. MOP 106532 to JLM), and the Institute of Nutrition, Metabolism, and Diabetes (No. MOP 119375 to (SB), as well as the St. Michael's Hospital Foundation. The Paediatric Outcomes Research Team is supported by a grant from The Hospital for Sick Children Foundation. PCP reports receiving a grant from Hospital for Sick Children Foundation and a grant from Canadian Institutes of Health Research (FRN \# 115059) for an ongoing investigator-initiated trial of iron deficiency in young children, for which Mead Johnson Nutrition provides non-financial support (Fer-In-Sol ${ }^{\oplus}$ liquid iron supplement) (2011-2017); and grants unrelated to this study for completed investigator-initiated studies from Danone Institute of Canada (2002-2004 and 2006-2009), Dairy Farmers of Ontario (2008-2010). JLM received an unrestricted research grant for a completed investigator-initiated study from the Dairy Farmers of Canada (2011-2012) and D-drops provided non-financial sup-port (vitamin D supplements) for an investigator initiated study on vitamin D and respiratory tract infections (2011-2015). CSB received a research grant from the Centre for Addiction and Mental Health Foundation (CAMH 2017-2020) and grants from Canadian Institutes of Health Research. CB reports previously receiving a grant for a completed investigator-initiated study from the SickKids Centre for Health Active Kids (CHAK) (2015-2016) involving the development and validation of a risk stratification tool to identify young asymptomatic children at risk for iron deficiency. These agencies had no role in the design, collection, analyses or interpretation of the results of this study or in the preparation, review, or approval of the manuscript. 


\section{Publisher's Note}

Springer Nature remains neutral with regard to jurisdictional claims in published maps and institutional affiliations.

\begin{abstract}
Author details
'Department of Family Medicine, Queen's University, 220 Bagot St., P.O. Bag 8888, Kingston, ON K7L5E9, Canada. ${ }^{2}$ Division of Paediatric Medicine and the Paediatric Outcomes Research Team (PORT), Hospital for Sick Children, Toronto, ON, Canada. ${ }^{3}$ Sick Kids Research Institute, Toronto, ON, Canada. ${ }^{4}$ Institute of Health Policy, Management and Evaluation, University of Toronto, Toronto, ON, Canada. ${ }^{5}$ Division of Paediatric Medicine, Department of Paediatrics, Faculty of Medicine, University of Toronto, Toronto, ON, Canada. ${ }^{6}$ Applied Health Research Centre (AHRC), Toronto, Canada. ${ }^{7}$ Li Ka Shing Knowledge Institute, St. Michael's Hospital, Toronto, ON, Canada. ${ }^{8}$ Kingston Community Health Centres, Kingston, Canada. ${ }^{9}$ Department of Paediatrics, St. Michael's Hospital, Toronto, ON, Canada. ${ }^{10}$ Department of Nutritional Sciences, Faculty of Medicine, University of Toronto, Toronto, ON, Canada.
\end{abstract}

\section{Received: 14 June 2018 Accepted: 17 September 2018} Published online: 24 September 2018

\section{References}

1. Grantham-McGregor S, Ani C. A review of studies on the effect of Iron deficiency on cognitive development in children. J Nutr. 2001;131:649S-68S

2. Skalicky A, Meyers AF, Adams WG, Yang Z, Cook JT, Frank DA. Child food insecurity and iron deficiency anemia in low-income infants and toddlers in the United States. Matern Child Health J. 2006;10(2):177-85 PubMed PMID: 16328705 .

3. Lozoff B, Jimenez E, Wolf A. Long-term developmental outcome of infants with iron deficiency. NEJM. 1991;325(10):687-94.

4. Walter T, de Andraca I, Chadud P, Perales CG. Iron deficiency Anemia: adverse effects on infant psychomotor development. Pediatrics. 1989;84(1):7-17.

5. Hartfield D. Iron deficiency is a public health problem in Canadian infants and children. Pediatric Child Health. 2010;15:347-50.

6. Brotanek JM, Gosz J, Weitzman M, Flores G. Iron deficiency in early childhood in the United States: risk factors and racial/ethnic disparities. Pediatrics. 2007; 120(3):568-75 PubMed PMID: 17766530.

7. Looker AC, Dallman PR, Carroll MD, Gunter EW, Johnson CL. Prevalence of iron deficiency in the United States. JAMA. 1997;277(12):973-6 PubMed PMID: 9091669

8. Carsley S, Borkhoff CM, Maguire JL, Birken CS, Khovratovich M, McCrindle B, et al. Cohort profile: the applied research Group for Kids (TARGet kids!). Int J Epidemiol. 2015:44(3):776-88. https://doi.org/10.1093/ije/dyu123.

9. Saunders NR, Parkin PC, Birken CS, Maguire JL, Borkhoff CM. Iron status of young children from immigrant families. Arch Dis Child. 2016;101:1130-6.

10. Sutcliffe TL, Khambalia A, Westergard S, Jacobson S, Peer M, Parkin PC. Iron depletion is associated with daytime bottle-feeding in the second and third years of life. Arch Pediatr Adolesc Med. 2006;160(11):1114-20. https://doi. org/10.1001/archpedi.160.11.1114 PubMed PMID: WOS:000241801700003.

11. Parkin PC, DeGroot J, Maguire JL, Birken CS, Zlotkin S. Severe iron-deficiency anaemia and feeding practices in young children. Public Health Nutr 2016; 19(4):716-722. Epub 2015/06/02. doi:https://doi.org/10.1017/S13689800150 01639. PubMed PMID: 26027426.

12. Maguire J, Lebovic G, Kandasamy S, Khovratovich M, Mamdani M, Birken C, et al. The relationship between Cow's Milk and Stores of Vitamin D and Iron in early childhood. Pediatrics. 2013;131:e144-51.

13. Maguire JL, Salehi L, Birken C, Carsley S, Mamdani M, Thorpe KE, et al. The association between total duration of breastfeeding and iron deficiency. Pediatrics. 2013;131:e144-e51.

14. Cox KA, Parkin PC, Anderson LN, Chen Y, Birken CS, Maguire $J$, et al. Association between meat and meat-alternative consumption and Iron Stores in Early Childhood. Acad Pediatr. 2016;16:783-91.

15. Abdullah K, Thorpe KE, Maguire JL, Birken CS, Fehlings D, Hanley AJ, et al. Risk factors, practice variation and hematological outcomes of children identified with non-anemic iron deficiency following screening in primary care setting. Paediatr Child Health. 2015;20(6):302-6 Epub 2015/10/06. PubMed PMID: 26435669: PubMed Central PMCID. PMCPMC4578469.

16. Glazier R, Rayner J, Kopp A. Examining Community Health Centres According to Geography and Priority Populations Served, 2011/12 to 2012/13. In: An ICES Chartbook. Toronto, ON: Institute for Clinical Evaluative Sciences; 2015.
17. Glazier R, Hutchison B, Kopp A. Comparison of family health teams to other Ontario primary care models, 2004/05 to 2011/12. Toronto: Institute for Clinical Evaluative Sciences; 2015

18. Parpia R, Borkhoff CM, Muldoon L, Rayner J, Birken C, Parkin P, et al. Association of measures of marginalization and use of Ontario community health Centres for preventative and social determinants of health-related care in young children. Pediatric Academic Societies; Toronto 2018.

19. Wong PD, Dave MG, Tulloch T, Feldman ML, Ford-Jones EL, Parkin PC, et al. Community health centres: potential opportunities for community paediatrics. From interprofessional clinical care to board governance. Paediatr Child Health. 2015;20(1):12-4. https://doi.org/10.1093/pch/20.1.12

20. Rourke Baby Record 2017 [Nov. 10, 2017]. Available from: http://www. rourkebabyrecord.ca/pdf/RBR\%202017\%200ntario\%20English\%20-\%20 Black\%20171004.pdf

21. Baker RD, Greer FR. The committee on N. diagnosis and prevention of Iron deficiency and Iron-deficiency Anemia in infants and young children (0-3 years of age). Pediatrics. 2010;126(5):1040-50. https://doi.org/10.1542/peds. 2010-2576.

22. World Health Organization. C-reactive protein concentrations as a marker of inflammation or infection for interpreting biomarkers of micronutrient status 2014 [Aug. 29, 2018].

23. CCHS CCHS. Canadian community health survey: statistics Canada; 2017 [May 4, 2017]. Available from: http://www23.statcan.gc.ca/imdb/p2SV pl?Function=getSurvey\&SDDS=3226.

24. Randall Simpson J, Keller H, Rysdale L, Beyers J. Nutrition screening tool for every preschooler (NutriSTEP): validation and test-retest reliability of a parent-administered questionnaire assessing nutrition risk of preschoolers. Eur J Clin Nutr. 2008:62:770-80

25. Randall Simpson J, Gumbley J, Whyte K, Lac J, Morra C, Rysdale L, et al. Development, reliability, and validity testing of toddler NutriSTEP: a nutrition risk screening questionnaire for children 18-35 months of age. Appl Physiol Nutr Metab. 2015:40:877-86.

26. National Health and Nutrition Examination Survey (NHANES) Anthropometry Procedures Manual. Centers for Disease Control, 2011.

27. Cogswell ME, Looker AC, Pfeiffer CM, Cook JD, Lacher DA, Beard JL, et al. Assessment of iron deficiency in US preschool children and nonpregnant females of childbearing age: National Health and nutrition examination survey 2003-2006. Am J Clin Nutr. 2009;89:1334-42.

28. Sypes E, Parkin PC, Birken CS, Carsley S, Macarthur C, Maguire JL, Borkhoff CM. Association between increased weight and iron deficiency in early childhood. Pediatrics 2018;142(1 Meeting Abstract).

29. Parkin PC, Maguire JL. Iron deficiency in early childhood. Can Med Assoc J. 2013:185:1237-8.

30. Hosmer DW, Lemeshow S. Applied logistic regression. New York: Wiley; 2000

31. Mickey RM, Greenland S. The impact of confounder selection criteria on effect estimation. Am J Epidemiol. 1989;129:125-37.

32. Little RJA, Rubin DB. Statistical analysis with missing data. New York, N.Y: Wiley; 2002

33. Egeland GM, Williamson-Bathory L, Johnson-Down L, Sobol I. Traditional food and monetary access to market-food: correlates of food insecurity among Inuit preschoolers. Int J Circumpolar Health. 2011;70(4):373-83 PubMed PMID: 21878183.

34. Pacey $\mathrm{A}$, Weiler $\mathrm{H}$, Egeland GM. Low prevalence of iron-deficiency anaemia among Inuit preschool children: Nunavut Inuit Child Health Survey, 20072008. Public Health Nutr. 2011;14(8):1415-23 https://doi.org/10.1017/S13689 80010002429. PubMed PMID: 20920385

35. Christofides A, Schauer C, Zlotkin SH. Iron deficiency and anemia prevalence and associated etiologic risk factors in first nations and Inuit communities in northern Ontario and Nunavut. Can J Public Health. 2005;96(4):304-7 PubMed PMID: 16625803

36. Willows ND, Morel J, Gray-Donald K. Prevalence of anemia among James Bay Cree infants of northern Quebec. CMAJ. 2000:162(3):323-6 PubMed PMID: 10693587; PubMed Central PMCID: PMCPMC1231010.

37. Willows ND, Dewailly E, Gray-Donald K. Anemia and iron status in Inuit infants from northern Quebec. Can J Public Health. 2000;91(6):407-10 PubMed PMID: 11200728

38. Metallinos-Katsaras E, Colchamiro R, Edelstein S, Sui E. Household food security status is associated with Anemia risk at age 18 months among low-income infants in Massachusetts. J Acad Nutr Diet. 2016;116(11):1760-6.

39. Brotanek JM, Gosz J, Weitzman M, Flores G. Secular trends in the prevalence of iron deficiency among US toddlers, 1976-2002. Arch Pediatr Adolesc Med. 2008;162(4):374-81. 
40. Verga ME, Widmeier-Pasche V, Beck-Popovic M, Pauchard JY, Gehri M. Iron deficiency in infancy: is an immigrant more at risk? Swiss Med Wkly. 2014;144: w14065.

41. Ferrara M, Bertocco F, Ricciardi A, Ferrara D, Incarnato L, Capozzi L. Iron deficiency screening in the first three years of life: a three-decade-long retrospective case study. Hematology. 2014;19(4):239-43.

42. Brotanek JM, Halterman JS, Auinger P, Flores G, Weitzman M. Iron deficiency, prolonged bottle-feeding, and racial/ethnic disparities in young children. Arch Pediatr Adolesc Med. 2005;159(11):1038-42 PubMed PMID: 16275794.

43. Grant $C C$, Wall $C R$, Yates $R$, Crengle $S$. Nutrition and indigenous health in New Zealand. J Paediatr Child Health. 2010;46(9):479-82.

44. McCann J, Ames B. An overview of evidence for a causal relationship between iron deficiency during development and deficits in cognitive or behavioural function. Am J Clin Nutr. 2007;85(4):931-45.

45. Walker SP, Wachs TD, Meeks Gardner J, Lozoff B, Wasserman GA, Pollitt E, et al. Child development: risk factors for adverse outcomes in developing countries. Lancet. 2007:369:145-57.

46. Lozoff B, Smith JB, Kaciroti N, Clark KM, Guevara S, Jimenez E. Functional significance of early-life Iron deficiency: outcomes at 25 years. J Pediatr. 2013;163:1260-6

47. Lozoff B, Jimenez E, Smith J. Double burden of iron deficiency in infancy and low socioeconomic status. A longitudinal analysis of cofnitive test scores to age 19 years. Arch Pediatr Adolesc Med. 2006;160:1108-13.

48. Baptist EC, Castillo SF. Cow's Milk-induced Iron deficiency Anemia as a cause of childhood stroke. Clin Pediatr. 2002;41:533-5.

49. Maguire JL, deVeber G, Parkin PC. Association between Iron-deficiency Anemia and stroke in young children. Pediatrics. 2007;120:1053-7.

50. Halfon N, Hochstein M. Life course health development : an integrated framework for developing health. Policy and Research The Milbank Quarterly. 2002;80(3):433-79.

51. Boivin M, Hertzman C, Barr RG, Boyce WT, Fleming A, MacMillan $\mathrm{H}$, et al. Early childhood development: adverse experiences and developmental health. Ottawa, ON: Royal Society of Canada- Canadian Academy of Health Sciences Expert Panel; 2012.

52. Shonkoff JP, Boyce WT, McEwen BS. Neuroscience, molecular biology, and the childhood roots of health disparities: building a new framework for health promotion and disease prevention. JAMA 2009:301(21):2252-2259.

53. Shonkoff JP, Garner AS, Committee on Psychosocial Aspects of C, Family H, Committee on Early Childhood A, Dependent C, et al. The lifelong effects of early childhood adversity and toxic stress. Pediatrics. 2011;129(1):e232-46 PubMed PMID: 22201156.

54. Garner AS, Shonkoff JP, Committee on Psychosocial Aspects of C, Family H, Committee on Early Childhood A, Dependent C, et al. Early childhood adversity, toxic stress, and the role of the pediatrician: translating developmental science into lifelong health. Pediatrics. 2012;129(1):e224-31 PubMed PMID: 22201148.

55. Felitti VJ, Anda RF, Nordenberg D, Williamson DF, Spitz AM, Edwards V, et al. Relationship of childhood abuse and household dysfunction to many of the leading causes of death in adults: the adverse childhood experiences (ACE) study. Am J Prev Med. 1998:14(4):245-58.

56. Association of Ontario Health Centres. Model of Health and Wellbeing [August 31, 2017]. Available from: https://www.allianceon.org/modelhealth-and-wellbeing.

Ready to submit your research? Choose BMC and benefit from:

- fast, convenient online submission

- thorough peer review by experienced researchers in your field

- rapid publication on acceptance

- support for research data, including large and complex data types

- gold Open Access which fosters wider collaboration and increased citations

- maximum visibility for your research: over $100 \mathrm{M}$ website views per year

At BMC, research is always in progress.

Learn more biomedcentral.com/submissions 